\title{
Evaluation of the role of mir-34b in modulation of radioresistance in non-small cell lung cancer
}

\author{
Joana B Silva ${ }^{1,3^{*}}$, Sílvia S Neves ${ }^{1,4}$, A Cristina Gonçalves ${ }^{1,4}$, Margarida Marques ${ }^{2,4}$, Luís Mesquita ${ }^{3}$, \\ Filomena Botelho ${ }^{2,4}$, A Bela Sarmento-Ribeiro ${ }^{1,4,5}$, Henriqueta C Silva ${ }^{3,4}$ \\ From 16th International Charles Heidelberger Symposium on Cancer Research \\ Coimbra, Portugal. 26-28 September 2010
}

Radiotherapy is a major therapeutic weapon in lung cancer. However, the resistance to radiotherapy is frequent. The microRNAs of the miR-34 family, miR34a, miR-34b and miR-34c, described as effector molecules in the cellular response to activation of P53, have low expression levels in lung cancer [1]. The mRNA of the anti-apoptotic protein BCL-2 is among the targets of miR-34 family.

The aims of our study were to clarify the involvement of miR-34b over-expression in the modulation of radiation response in NSCLC cell lines and the mechanisms involved. For these purposes we used two radioresistant NSCLC cell lines, A549, expressing P53, and H1299, not expressing P53. Cells transfected with pre-miR-34b or with a transfection control were exposed to different irradiation doses. The response to irradiation was assessed by cell survival curves obtained by clonogenic assay, and flow citometry allowed the characterization of cell death and the quantification of BCL-2, BAX and P53 protein expression levels. Our results showed that both cell lines had low expression levels of miR-34 family members, especially for miR-34b/c. Over-expression of miR-34b sensitized A549 cells to low doses of radiation and decreased BCL-2 expression, but without changing apoptosis levels. H1299 cells remained unchanged.

These results suggest that in NSCLC expressing P53, response to radiotherapy is dependent on BCL-2 levels and may be modulated by over-expression of miRNA34b. Other cell death mechanisms than apoptosis, but also involving BCL-2, like autophagy, could to be involved.

\footnotetext{
* Correspondence: joanabalca.silva@gmail.pt

'Department of Molecular Biology, Faculty of Medicine, University of

Coimbra (FMUC), Coimbra, Portugal

Full list of author information is available at the end of the article
}

Author details

'Department of Molecular Biology, Faculty of Medicine, University of Coimbra (FMUC), Coimbra, Portugal. ${ }^{2}|B| L I$, FMUC, Coimbra, Portugal.

${ }^{3}$ Medical Genetics, FMUC, University of Coimbra, Coimbra, Portugal.

${ }^{4}$ CIMAGO, FMUC, Coimbra, Portugal. ${ }^{5}$ Center for Neuroscience and Cell

Biology, University of Coimbra, Portugal.

Published: 24 September 2010

Reference

1. Iorio MV, Croce CM: MicroRNAs in Cancer: Small Molecules with a Huge Impact. J Clin Oncol 2009, 27:5848-56.

doi:10.1200/JCO.2009.24.0317

Cite this article as: Silva et al: Evaluation of the role of mir-34b in modulation of radioresistance in non-small cell lung cancer. BMC Proceedings 2010 4(Suppl 2):P11.

Submit your next manuscript to BioMed Central and take full advantage of:

- Convenient online submission

- Thorough peer review

- No space constraints or color figure charges

- Immediate publication on acceptance

- Inclusion in PubIMed, CAS, Scopus and Google Scholar

- Research which is freely available for redistribution

Submit your manuscript at www.biomedcentral.com/submit 